\title{
Auxin type and dilution vehicles on vegetative propagation of Varronia curassavica Jacq. and Melaleuca alternifolia Cheel
}

\author{
Marcelo Pereira ${ }^{1}$ (D), Lilian Fernanda Sfendrych Gonçalves² (1), \\ Erik Nunes Gomes ${ }^{1}\left(\mathbb{D}\right.$, Überson Boaretto Rossa ${ }^{2 *} \mathbb{D}$, Cícero Deschamps ${ }^{1}(\mathbb{D}$ \\ ${ }^{1}$ Universidade Federal do Paraná, Setor de Ciências Agrárias, Curitiba-PR, Brazil. \\ ${ }^{2}$ Instituto Federal Catarinense, Setor de Ciências Agrárias, Araquari-SC, Brazil.
}

\begin{abstract}
Studies on the propagation of medicinal and ornamental plant species show of great relevance as they contribute to the domestication, cultivation and production of these species. However, there are not enough information concerning the interaction of the different plant growth regulators and the recommended dilution vehicles. This work aimed to evaluate the effects of sodium hydroxide $(\mathrm{NaOH})$ and ethanol as rooting inducers, as well as their performance as vehicles for diluting indolebutyric acid (IBA) and naphthalene acetic acid (NAA) in stem cuttings of the species Varronia curassavica and Melaleuca alternifolia. Stem cuttings of both species were submitted to the treatments: control with distilled water, hydroethanolic solution $\left(50 \% \mathrm{v} \mathrm{v}^{-1}\right), \mathrm{NaOH}$ solution in distilled water, indolebutyric acid diluted in hydroethanolic solution, indolebutyric acid diluted in $\mathrm{NaOH}$ solution, naphthalene acetic acid diluted in hydroethanolic acid and naphthalene acetic acid diluted in $\mathrm{NaOH}$ solution $(0.5 \mathrm{~N})$. The design used was completely randomized, with the averages compared by the Scott-Knott test at 5\% probability. Better rooting of the cuttings was observed when IBA was applied using both dilution vehicles. For M. alternifolia, percentages of average survival of $26.43 \%$ were verified. Rooting was more satisfactory when using $\mathrm{NaOH}$ as a dilution vehicle for both IBA (16.66\%) and NAA (23.33\%). For $V$. curassavica, IBA $\left(2000 \mathrm{mg} \mathrm{L}^{-1}\right)$ is the most suitable plant regulator, diluted in both hydroethanolic solution and in $\mathrm{NaOH}$, while for M. alternifolia, $\mathrm{NaOH}$ is recommended as a dilution vehicle for plant growth regulators NAA $\left(500 \mathrm{mg} \mathrm{L}^{-1}\right)$ and IBA $\left(500 \mathrm{mg} \mathrm{L}^{-1}\right)$. When applied isolated, the dilution vehicles do not stimulate and do not harm the rooting of the two species.
\end{abstract}

Keywords: black sage, ethanol, indolebutyric acid, naphthalene acetic acid, sodium hydroxide, tea tree.

\section{Resumo}

Tipo de auxina e veículos de diluição para a propagação vegetativa de Varronia curassavica Jacq e Melaleuca alternifolia Cheel

Estudos sobre propagação de espécies vegetais medicinais e ornamentais são de grande relevância por contribuírem para a sua domesticação, cultivo e produção. Entretanto, ainda há escassez de informações acerca da interação dos diferentes reguladores vegetais e veículos de diluição recomendados. Este trabalho objetivou avaliar os efeitos do hidróxido de sódio $(\mathrm{NaOH})$ e do etanol como indutores de enraizamento, bem como seu desempenho como veículos de diluição do ácido indolbutírico (AIB) e do ácido naftalenoacético (ANA) em estacas caulinares das espécies Varronia curassavica e Melaleuca alternifolia. Estacas caulinares das duas espécies foram submetidas aos tratamentos: controle com água destilada, solução hidroetanólica $\left(50 \% \mathrm{v} \mathrm{v}^{-1}\right)$, solução de $\mathrm{NaOH}(0.5 \mathrm{~N})$ em água destilada, ácido indolbutírico diluído em solução hidroetanólica, ácido indolbutírico diluído em solução de $\mathrm{NaOH}$, ácido naftalenoacético diluído em solução hidroetanólica e ácido naftalenoacético diluído em solução de $\mathrm{NaOH}$. $\mathrm{O}$ delineamento utilizado foi o inteiramente casualizado, sendo as médias comparadas pelo teste Scott-Knott a 5\% de probabilidade. $\mathrm{O}$ enraizamento das estacas foi mais satisfatórios quando aplicado AIB em ambos os veículos de diluição. Para M. alternifolia, verificaram-se percentagens de sobreviência média de 26,43\%. O enraizamento se mostrou mais satisfatório quando utilizado o $\mathrm{NaOH}$ como veículo de diluição tanto AIB (16,66\%) quanto ANA (23,33\%). Para $V$. curassavica o AIB é o regulador vegetal mais indicado, diluído tanto em solução hidroetanólica quanto em $\mathrm{NaOH}$, enquanto para $M$. alternifolia recomenda-se o $\mathrm{NaOH}$ como veículo de diluição dos reguladores vegetais ANA (500 mg L-1) e AIB (500 $\left.\mathrm{mg} \mathrm{L}^{-1}\right)$. Isoladamente, os veículos de diluição não estimulam e não prejudicam o enraizamento das duas espécies.

Palavras-Chave: ácido indolbutírico, ácido naftalenoacético, erva-baleeira, etanol, hidróxido de sódio, melaleuca.

${ }^{*}$ Corresponding author: boarettorossa@gmail.com

https://doi.org/10.1590/2447-536X.v27i2.2253

Received Aug 31, $2020 \mid$ Accepted Feb 06, 2021 | Available online Mar 10, 2021

Licensed by CC BY 4.0 (https://creativecommons.org/licenses/by/4.0/)

Area Editor: Ana Maria Mapeli 


\section{Introduction}

Studies on the propagation of medicinal and ornamental plant species have shown to be of high importance, since they are the initial stages in the cultivation of these plants and determinants in the quality of the final product (Gomes and Krinski, 2016b; Gomes et al., 2018b; Luz, 2019). Among the medicinal and ornamental plants cultivated in Brazil, the species Varronia curassavica Jacq. (Boraginaceae) and Melaleuca alternifolia Cheel (Myrtaceae) stand out for their ornamental potential as well as for the production of essential oils with several applications in the herbal, cosmetic and agrochemical industries.

$V$. curassavica, popularly known as black sage (scientific synonym Cordia verbenacea DC.), is a plant of vigorous growth, found from Central America to the South of Brazil, being characteristic of the sandy coastal plain of Ceará until Rio Grande do Sul (Lorenzi and Matos, 2008; Mendes et al., 2014). Although not commonly used for ornamental purposes, $V$. curassavica has an interesting potential in this regard, with a shrubby growth habit, dense inflorescences and white flowers, visited by a series of pollinators mainly Coleoptera, Hemiptera, Diptera and Hymenoptera (Brandão et al., 2015; Marques et al., 2019). Given the adaptability of the species to sandy areas of the Restinga (Hoeltgebaum and Reis, 2017) a seriously threatened ecosystem in Brazil, V. curassavica can consist of a strategic species to compose projects of functional landscaping, where plants are grown, in addition to their ornamental features, by their ecological functions or economic uses, integrating decoration with functionality (Alencar and Cardoso, 2015)

Currently, however, the importance of $V$. curassavica comes mainly from the production of essential oil, commercially used in the form of analgesic and antiinflammatory drugs and muscle relaxants (Gilbert and Favoreto, 2012; Marques et al., 2019). Among these drugs, the topical anti-inflammatory Acheflan $\AA$, an herbal medicine, stands out. When the product was released in 2005 , it caused an impact on the Brazilian pharmaceutical industry, as a result of innovation regarding the production of goods entirely with national resources (Queiroz et al., 2009).

Black sage is usually propagated by seeds, which can lead to changes in the content of the active ingredient in function of genetic variability and other factors (Gilbert and Favoreto, 2012), in this sense vegetative propagation can become an alternative for propagation and establishing more homogeneous crops.

M. alternifolia is an Australian tree native, more specifically to the region of New South Wales (Oliveira et al., 2020), known worldwide as "tea tree". The plant possesses great ornamental potential (Oliveira, 2009), and can be used to compose garden hedges as well as windbreaks, being also planted to stabilize embankments (Plants of the world, 2020). The plant can also be considered for functional landscaping, since, in addition to ornamental characteristics, $M$. alternifolia is also grown for the essential oil extracted from the leaves, mainly used by the pharmaceutical and cosmetics industries, due to its antifungal and antibacterial properties (Oliveira et al., 2012). In an economic analysis of a tea tree plantation carried out by Castro et al. (2005a), it was observed that with a population of 10,000 plants $^{-1} \mathrm{~h}^{-1}(1 \mathrm{~m} \times 1 \mathrm{~m})$ a yield of $81.6 \mathrm{~L} \mathrm{ha}^{-1}$ year ${ }^{-1}$ of essential oil was obtained, which generated positive economic indexes and enabled the generation of jobs.

The propagation of tea tree can be considered an obstacle, because although there are recommendations for propagation via seed, vegetative propagation is the most appropriate method aiming at better quality and homogeneity, considering the active ingredient as the final product (Oliveira, 2009). However, the feasibility of practices such as the vegetative propagation of the species by cuttings still shows the need to be improved.

Asexual propagation methods are alternatives for the rapid multiplication of plants, allowing the formation of homogeneous crops in terms of productivity and anticipation of the commercial production (Gomes and Krinski, 2018; Vieira et al., 2018). Among the asexual propagation techniques, one of the most commonly used in the propagation of medicinal species is the stem cutting technique (Gomes et al., 2018a). Cutting propagation is based on the regeneration of a new plant from a segment of the parental plant, whether it comes from the root, stem or leaf. It is an advantageous method for medicinal plants because of the ease of execution, the low cost and the number of plants that can be obtained from a single mother plant (Fachinello et al., 1994). Studies on propagation via cuttings have been concentrated, especially, in the verification of the best types and lengths of cuttings, in the effect of the use of plant growth regulators and in the most suitable substrates for rooting. (Pigatto et al., 2018; Belniaki et al., 2019; Gomes and Krinski, 2019; Latoh et al., 2019).

Among the most used plant growth regulators are synthetic auxins, including indolebutyric acid (IBA) and naphthalene acetic acid (NAA), responsible for providing a higher percentage, speed, quality and uniformity of rooting (Hartmann et al., 2011). However, little is reported in the literature about the influence of the dilution vehicles used and indicated for the application of commercial products.

The hydroethanolic solution, one of the most widely used in the dilution of auxins for application in cuttings, may, according to some authors, stimulate rooting, since ethanol can be a carbon source capable of meeting the carbohydrate demands of vegetative propagules (Middleton et al., 1978; Bhattacharya et al., 1985). On the other hand, Wendling et al. (2013) point out that alcohol can have a toxic effect on cuttings, in the absence of IBA. In a study by Oliveira et al. (2009), there were no differences in the dilution of auxins in hydroethanolic solution or sodium hydroxide $(\mathrm{NaOH})$ in the rooting of stem cuttings of Olea europaea L. In view of the contradictory results found in the literature, studies are needed evaluating the effect of the vehicles of dilution of auxins in vegetative propagation.

Therefore, this study aimed to evaluate the effects of $\mathrm{NaOH}$ and ethanol as rooting inducers, as well as their 
performance as dilution vehicles of IBA and NAA in stem cuttings of the species $V$. curassavica and M. alternifolia.

\section{Material and Methods}

The experiment was carried out in under greenhouse conditions, in the Sector of Agricultural Sciences of the Federal University of Paraná, in the city of Curitiba-PR, coordinates $25^{\circ} 25^{\prime} 40^{\prime \prime} \mathrm{S}$ and $49^{\circ} 16^{\prime} 23^{\prime \prime} \mathrm{W}$, at an altitude of $934 \mathrm{~m}$.

The cuttings were obtained from parental plants grown in the Sector of Medicinal, aromatic and spice plants, located in the Center of Experimental Stations of Canguiri (CEExFederal University of Paraná), municipality of PinhaisPR ( $25^{\circ} 25^{\prime} 16^{\prime \prime} \mathrm{S}$ and $49^{\circ} 08$ ' $26^{\prime}$ " W), at an altitude of $900 \mathrm{~m}$. The climate of the region according to the Köppen classification is humid temperate $\mathrm{Cfb}$, with mild summer, cold and dry winter, rains evenly distributed throughout the year and the occurrence of frequent severe frosts. Plant material collection took place on August 16, 2017, in the morning (between 8 and 9 am), under conditions of cloudy weather and mild climate $\left(15^{\circ} \mathrm{C}\right)$. Leafy branches were collected with the help of pruning shears and packed in plastic trays for transport to the place where the cuttings were prepared. The time between the collection of plant material and the planting of the cuttings was approximately 3 hours for V. curassavica and 5 hours for M. alternifolia. During this period the plant material was kept in trays with water to prevent dehydration.

The vegetative material of $V$. curassavica was collected from 10 mother plants in vegetative stage, approximately 8 years old. Young shoots of the year with herbaceous consistency, collected from regrowth were collected (Figures 1A, 1B).

The semi-hardwood branches of M. alternifolia were collected from 8 parental plants (clones) of the chemotype terpinen-4-ol (Figure 2A). The mother plants were obtained by cutting and cultivated for approximately 5 years.
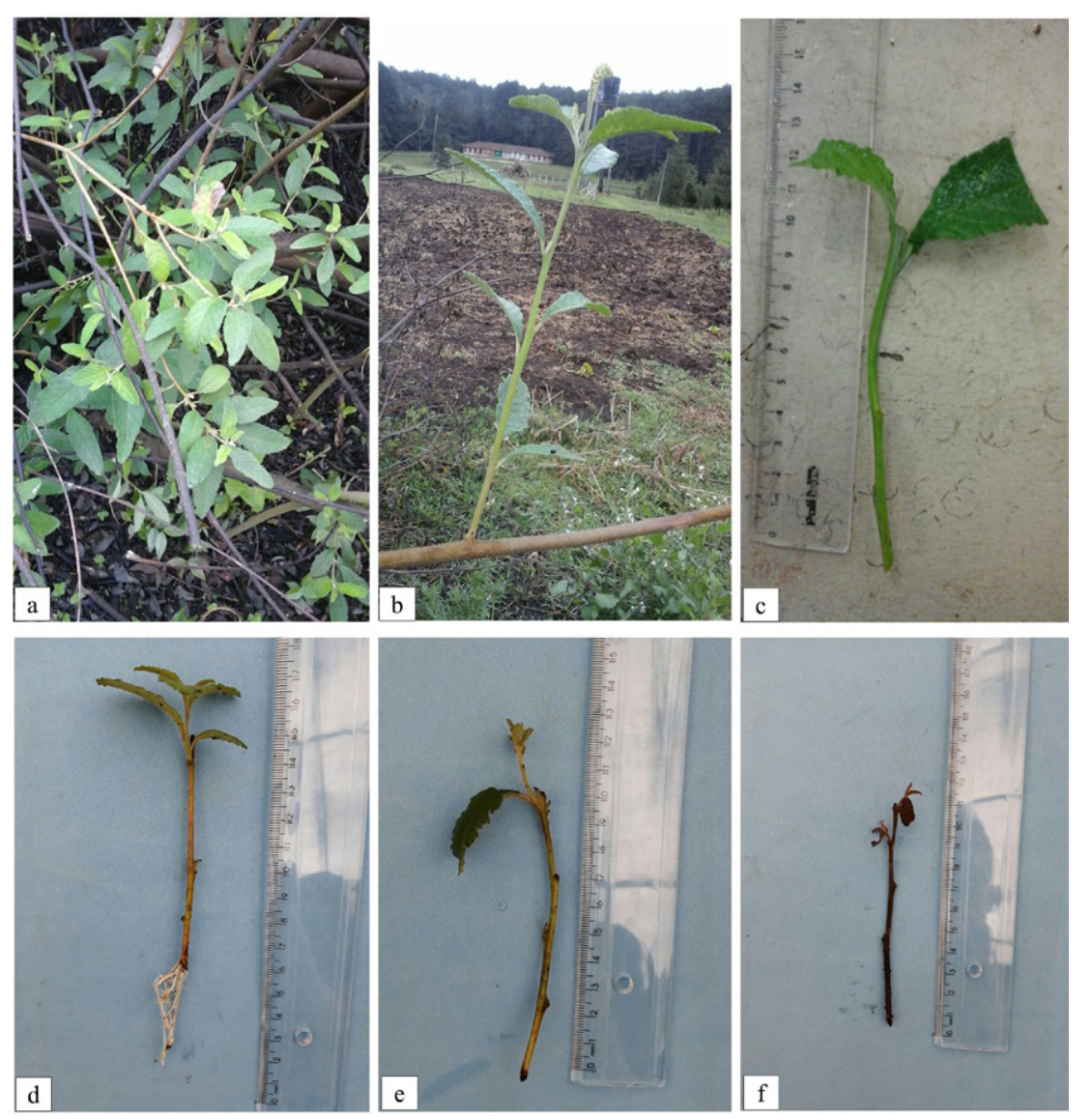

Figure 1. Branches and stem cuttings of V. curassavica. A and B: Herbaceous branches of the year (regrowth) used for making the cuttings. C: Herbaceous stem cuttings of black sage used in the experiment. D: Aspect of rooted cuttings of $V$. curassavica 45 days after planting. E: Non-rooted alive cutting with new shoots emitted, 45 days after planting. F: Aspect of $V$. curassavica dead cutting (all necrotic tissues). 


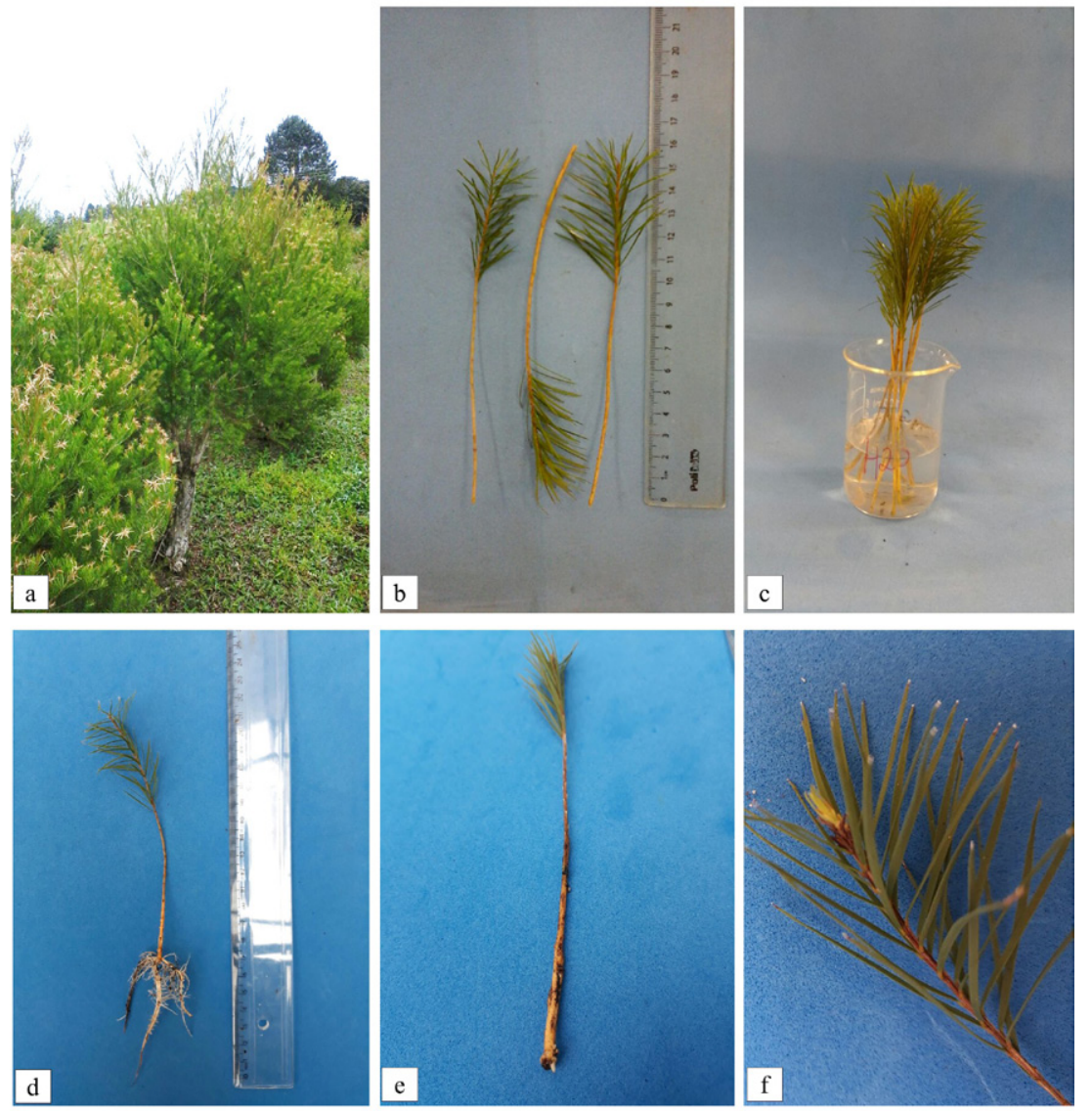

Figure 2. Branches and stem cuttings of $M$. alternifolia. A: Mother plant with semi-hardwood branches used for making the cuttings. B: semi-hardwood stem cuttings of $M$. alternifolia. C: immersion of the base of the cuttings in the control treatment (distilled water). D and E: Aspect of rooted cuttings of M. alternifolia 76 days after planting. Detail for the difference in the stage of development of the roots, completely developed in D and in an initial stage in E. F:

Emission of new shoots in cuttings of $M$. alternifolia 76 days after planting.

The herbaceous stem cuttings of black sage were prepared $10 \pm 2 \mathrm{~cm}$ long and $0.1 \pm 0.03 \mathrm{~cm}$ in diameter, with a bevel cut at the base and transversal above the last axillary bud (Figure 1C), leaving two leaves with half of the original area (Bischoff et al., 2017).

For $M$. alternifolia, the semi-hardwood stem cuttings were made from the apical region of the branches, $15 \pm 2$ $\mathrm{cm}$ long and $0.4 \pm 0.05 \mathrm{~cm}$ in diameter (Figure $2 \mathrm{~B}$ ). The cuttings were prepared with a bevel cut at the base and a straight cut at the apex, keeping one third of the leaves in the upper portion (Oliveira et al., 2012).

After preparation, cuttings of both species were submitted to phytosanitary treatment with $0.5 \%\left(\mathrm{v} \mathrm{v}^{-1}\right)$ sodium hypochlorite for 15 minutes and rinsed in running water for 5 minutes.

After the phytosanitary procedure, the cuttings were subjected to treatments with auxins and dilution vehicles. For each species, 7 treatments were used: control treatment with distilled water (T1), hydroethanolic solution (T2), sodium hydroxide solution in distilled water (T3), indolebutyric acid diluted in hydroethanolic solution (T4), indolebutyric acid diluted in solution sodium hydroxide (T5), naphthalene acetic acid diluted in hydroethanolic solution (T6) and naphthalene acetic acid diluted in sodium hydroxide solution (T7).

The hydroethanolic solution was prepared at a concentration of $50 \%\left(\mathrm{v} \mathrm{v}^{-1}\right)$, using $50 \mathrm{ml}$ of distilled water and $50 \mathrm{ml}$ of anhydrous ethanol (Alphatec ${ }^{\mathbb{R}}$ ). The sodium hydroxide solution was prepared at $0.5 \mathrm{~N}$ in $100 \mathrm{ml}$ of water. The definition of the concentration of indolebutyric acid for both species was carried out according to literature recommendations. The concentration of naphthalene acetic acid was equivalent to that recommended for indolebutyric acid.

For V. curassavica, the concentration of $2000 \mathrm{mg}$ $\mathrm{L}^{-1}$ IBA was used (MENDES et al., 2014) and the equivalent solution, $2000 \mathrm{mg} \mathrm{L}^{-1} \mathrm{NAA}$. Both regulators were diluted in $50 \mathrm{ml}$ of alcohol or $0.5 \mathrm{~N} \mathrm{NaOH}$ in beakers and the volume was completed with distilled water. For $M$. alternifolia, the concentration of $500 \mathrm{mg}$ L $^{-1}$ IBA (OLIVEIRA et al., 2012) and the equivalent for NAA was used. The dilutions of the treatments were carried out according to the described for V. curassavica. Indolebutyric acid from the commercial brand $\mathrm{Vetec}^{\circledR}$, with $98 \%$ purity and naphthalene acetic acid from the brand Sigma-Aldrich ${ }^{\circledR}$, with $97 \%$ purity, were used. 
The cuttings of the two species were grouped in bundles of 10 and had their base immersed in the solution corresponding to the treatment used, for a period of ten seconds (Figure 2C). After this procedure, they were planted in Styrofoam trays of 128 cells $\left(40 \mathrm{~cm}^{-3}\right.$ per cell), filled with commercial substrate Tropstrato $\mathrm{HT}^{\circledR}$. The trays with the cuttings were placed on benches in the greenhouse with intermittent misting for 10 seconds every 30 minutes (8:00 am to $10: 00 \mathrm{pm})$ and every 180 minutes $(10: 00 \mathrm{pm}$ to 8:00 am), where they remained until the final evaluations.

The black sage cuttings were evaluated 45 days after planting, on September 30, 2017. For M. alternifolia, the evaluation occurred 76 days after planting, on October 31, 2017.

The cuttings of the two species were evaluated for the following variables: percentages of survival, rooting, cuttings with emission of new shoots (sprouting) and cuttings with leaf retention; average number of roots and average length of roots.

Cuttings, rooted or not, which did not present tissue necrosis, were considered alive. Live cuttings that had a visible root of at least $0.1 \mathrm{~cm}$ were considered rooted (Figures 1D, 2D and 2E). Cuttings that presented necrotic tissues were considered dead (Figure 1F). For the leaf retention variable, cuttings that maintained at least one leaf in the case of $V$. curassavica and those that remained with some portion of the leaf area in the case of M. alternifolia were considered.

The average number of roots was obtained by counting the total number of roots for each cutting within the plot divided by the number of cuttings in the plot. The average length of roots per plot was obtained by the arithmetic average of the lengths of the three largest roots of each cutting within the plot.

The experimental design was completely randomized (CRD) with 7 treatments, 4 replications and 10 cuttings as a sample unit for each of the species. The data were graphically analyzed for normality and independence of residues and subjected to the analysis of homogeneity of variances by the Bartlett test. For the variables that met the assumptions, ANOVA analysis of variance was performed and, when significant, the averages were compared by the Scott-Knott test at 5\% probability. For the variables with non-homogenous variances, even after transformation of the data, the analysis was carried out using the Kruskal-Wallis non-parametric test. The analyzes were performed using the statistical software Assistat (Silva and Azevedo, 2016).

\section{Results and Discussion}

\section{Experiment with Varronia curassavica}

The survival of $V$. curassavica cuttings was not affected by the treatments. The average for this variable was $30.47 \%$ (Table 1), a value that can be considered low when compared to cuttings of several medicinal and ornamental species, such as coleus (Plectranthus scutellarioides (L.) R. Br) (Belniaki et al., 2019), tibouchinas (Tibouchina spp.) (Latoh et al., 2019) and cidreira (Lippia alba (Mill.) NE Br. ex P. Wilson) (Gomes et al., 2018b) where values above $90 \%$ of survival were observed even without the application of plant growth regulators. When compared to studies carried out with the same species, however, survival is close to that reported by Bischoff et al. (2017), with an average of $34.58 \%$ for cuttings made also with two leaves. In another study, using different substrate options for propagation by cuttings in $V$. curassavica, Mendes et al. (2014) observed a mortality rate close to $74 \%$ using commercial substrate. The high mortality of cuttings may be related to seasonality, dehydration, and endogenous characteristics of the species, such as the presence of phenolic compounds (Mendes et al., 2014).

Table 1. Percentages of survival (S), rooting (R), leaf retention (LR), sprouting (Sp), number of roots (N), and root length (L) in stem cuttings of Varronia curassavica Jacq. According to different treatments.

\begin{tabular}{|c|c|c|c|c|c|c|}
\hline Treatments & $\begin{array}{c}\text { S } \\
(\%)\end{array}$ & $\begin{array}{c}\mathbf{R} \\
(\%)\end{array}$ & $\begin{array}{l}\mathbf{L R}^{*} \\
(\%)\end{array}$ & $\begin{array}{c}\text { Sp } \\
(\%)\end{array}$ & $\begin{array}{c}\mathbf{N} \\
\text { (n) }\end{array}$ & $\begin{array}{c}\mathrm{L} \\
(\mathrm{cm})\end{array}$ \\
\hline CONT & $33.33^{\text {ns }}$ & $3.33 \mathrm{~b}$ & $18.25^{\text {ns }}$ & $30.00^{\mathrm{ns}}$ & $0.66^{\mathrm{ns}}$ & $0.26^{\mathrm{ns}}$ \\
\hline ET & 30.00 & $8.88 \mathrm{~b}$ & 13.00 & 30.00 & 2.25 & 1.08 \\
\hline $\mathrm{NaOH}$ & 33.33 & $3.33 \mathrm{~b}$ & 13.00 & 33.33 & 2.66 & 1.50 \\
\hline IBA+ET & 30.00 & $13.33 \mathrm{a}$ & 18.25 & 30.00 & 4.13 & 1.48 \\
\hline $\mathrm{IBA}+\mathrm{NaOH}$ & 40.00 & $20.00 \mathrm{a}$ & 13.00 & 40.00 & 2.25 & 1.70 \\
\hline NAA+ET & 23.33 & $6.66 \mathrm{~b}$ & 13.00 & 23.33 & 2.00 & 0.93 \\
\hline $\mathrm{NAA}+\mathrm{NaOH}$ & 23.33 & $6.66 \mathrm{~b}$ & 13.00 & 23.33 & 6.66 & 1.92 \\
\hline Average & 30.47 & 8.89 & 14.50 & 30.00 & 2.94 & 1.27 \\
\hline C.V. $(\%)$ & 44.54 & 57.09 & - & 47.15 & 79.90 & 83.48 \\
\hline Bartlett $\left(\mathrm{X}^{2}\right)$ & 13.03 & 5.67 & 97.68 & 13.13 & 9.87 & 7.21 \\
\hline
\end{tabular}

CONT: control treatment with distilled water; ET: hydroethanolic solution $\left(50 \% \mathrm{v} \mathrm{v}^{-1}\right)$; $\mathrm{NaOH}$ : $0.5 \mathrm{~N}$ sodium hydroxide solution; IBA+ET: 2000 mg $\mathrm{L}^{-1}$ of indolebutyric acid diluted in hydroethanolic solution; IBA+NaOH: $2000 \mathrm{mg} \mathrm{L}^{-1}$ of indolebutyric acid diluted in sodium hydroxide solution; NAA+ET $2000 \mathrm{mg} \mathrm{L}^{-1}$ naphthalene acetic acid diluted in hydroethanolic solution; NAA+NaOH: $2000 \mathrm{mg} \mathrm{L}^{-1}$ of naphthalene acetic acid diluted in sodium hydroxide solution.

C.V.: Coefficient of variation. Averages followed by the same letter, in the column, do not differ by the Scott-Knott test at $5 \%$ probability. * Non-homogeneous variances, averages compared by the Kruskal-Wallis test. 
The values observed for rooting in this study are also relatively low, with an average of $8.89 \%$. In the case of Bischoff et al. (2017), the authors attributed the low values of rooting in $V$. curassavica to seasonality, low leaf retention and high percentages of shoots to the detriment of rooting. As there was a relatively high percentage of sprouted cuttings in the experiment, this would indicate that most of the reserves present in the material were translocated before to the formation of shoots instead of roots, which would partially explain the low percentages of rooting (Bischoff et al., 2017). As for seasonality the authors emphasize the cuttings were collected in winter, which may, in some cases, be unfavorable to adventitious rooting due to morphophysiological adaptations and hormonal balance in the parent plants (Bischoff et al., 2017).

In this study, although the sprouting values are not as expressive, they were also considerably higher than those observed for rooting, which may indicate some contribution to high mortality and low percentage of rhizogenesis. Figure 1E shows a cutting with new sprouts and no roots.

The low percentages of leaf retention, regardless of treatments (average of $14.50 \%$ ), may also indicate some reasons for low rooting percentages of $V$. curassavica. In fact, it was possible to observe leaf abscission starting 4 days after planting the cuttings, which harms survival and rooting, since leaves are sources of photoassimilates, hormones and co-factors related to rooting (Hartmann et al., 2011; Beliniaki et al., 2019;).

Despite the low rooting values, treatments influenced the adventitious rhizogenesis in $V$. curassavica cuttings. The application of IBA, diluted in both ethanol and $\mathrm{NaOH}$, was superior to the other treatments for this variable. It is known that the application of exogenous auxins in plant species serves to increase the percentage, speed, quality and uniformity in rooting (Pigatto et al., 2018; Machado et al., 2018; Gomes and Krinski, 2020). In this sense, indolebutyric acid is one of the most used because it is one of the most efficient due to the characteristics of being photostable, not presenting toxicity over a wide concentration range, having greater chemical stability and being immune to biological action (Tofanelli et al., 2002; Hartmann et al., 2011). The results observed comparing the plant growth regulators IBA and NAA in the present study, corroborate those reported by Mendes et al. (2014), who reported that IBA is the most suitable for this species.
The same authors also concluded that NAA is a more toxic auxin than IBA, and should therefore be used in lower concentrations.

It can be seen that the IBA had a stimulatory effect independent of the dilution vehicle used, indicating that both can be recommended for association with this plant growth regulator. A similar result was reported by Oliveira et al. (2009), who reported that there are no differences in the dilution of IBA by alcohol or $\mathrm{NaOH}$ for stem cuttings of Olea europaea L.

Neither IBA nor ANA affected the roots number and length on $V$. curassavica cuttings. The effect of plant growth regulators on roots number and length are speciesdependent and species such as Piper crassinervium (Gomes and Krinski, 2018), Plectranthus scutellarioides (Belniaki et al., 2019) and $V$. curassavica (Bischoff et al., 2017), among others, have been previously reported as to not being affected by synthetic auxins regarding roots number and length.

Another important point of the results of this experiment is the fact that the ethanolic solution, without auxins, does not stimulate the rhizogenesis in $V$. curassavica cuttings, since it did not differ from the control treatment. Some authors claim that ethanol is a carbon source

capable of stimulating rooting and root growth in stem cuttings (Bhattacharya et al., 1985; Wendling et al., 2013), however, for this species, such behavior was not observed for rooting percentage, which was influenced only by IBA. In the variables related to the development of the roots (number and length), there was also no stimulating effect of ethanol, since these variables did not differ depending on the treatments (Table 1).

\section{Experiment with Melaleuca alternifolia}

For M. alternifolia, there was low survival of cuttings (average of $26.43 \%$ ), which was not affected by the treatments (Table 2). This data can be compared to the work by Oliveira et al. (2008), with the same species, where the best survival performance (cuttings with a length of $10 \mathrm{~cm}$ ) was $45 \%$. An important factor that may justify the high mortality and low rooting percentages of the cuttings (average of $13.33 \%$ ) in the present study is their small diameter (on average $0.1 \mathrm{~cm}$ ), which results in a small amount of reserves, possibly not sufficient for rooting and consequent formation of quality plants (Gomes and Krinski, 2016b; Gomes et al., 2018b). 
Table 2. Percentages of survival (S), rooting (R), leaf retention (LR), sprouting (Sp), number of roots (N), and root length (L) in stem cuttings of Melaleuca alternifolia Cheel. according to different treatments.

\begin{tabular}{|c|c|c|c|c|c|c|c|}
\hline Treatments & $\mathbf{S ~ ( \% )}$ & $\mathbf{R}(\mathbf{\%})$ & $\mathbf{L R}(\mathbf{\%})$ & $\mathbf{S p} \boldsymbol{( \% )}$ & $\mathbf{N}(\mathbf{n})$ & $\mathbf{L}(\mathbf{c m})$ \\
\hline CONT & $24.16^{\mathrm{ns}}$ & $10.00 \mathrm{~b}$ & $26.66^{\mathrm{ns}}$ & $3.33^{\mathrm{ns}}$ & $0.66 \mathrm{~b}$ & $0.78 \mathrm{~b}$ \\
\hline ET & 27.5 & $6.66 \mathrm{~b}$ & 30.0 & 0.00 & $1.0 \mathrm{~b}$ & $0.45 \mathrm{~b}$ \\
\hline $\mathrm{NaOH}$ & 16.66 & $13.33 \mathrm{~b}$ & 16.66 & 6.67 & $2.44 \mathrm{a}$ & $2.49 \mathrm{a}$ \\
\hline IBA+ET & 23.33 & $16.66 \mathrm{a}$ & 23.33 & 0.00 & $2.55 \mathrm{a}$ & $1.21 \mathrm{~b}$ \\
\hline IBA+NaOH & 30.0 & $16.66 \mathrm{a}$ & 30.0 & 6.67 & $2.50 \mathrm{a}$ & $3.44 \mathrm{a}$ \\
\hline NAA+ET & 33.33 & $6.66 \mathrm{~b}$ & 33.3 & 0.00 & $0.66 \mathrm{~b}$ & $0.50 \mathrm{~b}$ \\
\hline NAA+NaOH & 30.0 & $23.33 \mathrm{a}$ & 30.0 & 0.00 & $2.66 \mathrm{a}$ & $1.25 \mathrm{~b}$ \\
\hline Overall average & 26.43 & 13.33 & 27.14 & 2.38 & 1.78 & 1.44 \\
\hline C.V. $(\%)$ & 25.45 & 40.09 & 49.99 & - & 61.55 & 64.9 \\
\hline Bartlett $\left(\mathrm{X}^{2}\right)$ & 3.31 & 1.76 & 8.47 & 81.03 & 10.33 & 13.11 \\
\hline
\end{tabular}

CONT: control treatment with distilled water; ET: hydroethanolic solution $\left(50 \% \mathrm{v} \mathrm{v}^{-1}\right)$; $\mathrm{NaOH}$ : $0.5 \mathrm{~N}$ sodium hydroxide solution; IBA+ET: 500 mg L $\mathrm{L}^{-1}$ of indolebutyric acid diluted in hydroethanolic solution; IBA+NaOH: $500 \mathrm{mg} \mathrm{L}^{-1}$ of indolebutyric acid diluted in sodium hydroxide solution; $\mathrm{NAA}+\mathrm{ET}$ $500 \mathrm{mg} \mathrm{L}^{-1}$ naphthalene acetic acid diluted in hydroethanolic solution; NAA+NaOH: $500 \mathrm{mg} \mathrm{L}^{-1}$ of naphthalene acetic acid diluted in sodium hydroxide solution.C.V.: Coefficient of variation. Averages followed by the same letter, in the column, do not differ by the Scott-Knott test at $5 \%$ probability. * Non-homogeneous variances, averages compared by the Kruskal-Wallis test.

Sprouting rates were very low in all treatments, which consists of a drawback in terms of plant propagation, as shoot emission is an important characteristic for the formation of quality plants, since, after depletion of the cutting reserves, the presence of new leaves is essential for plant nutrition (Gomes and Krinski, 2016a). New sprouts, were, however observed in a few cuttings (Figure 2F), evidencing that the species is capable of emitting new shoots from stem cuttings.

On the other hand, leaf retention remained constant in all treatments, probably due to the species' own morphophysiology, which has a large number of leaves per stem area and low abscission rate, which does not interfere in the criteria of presence or absence of leaves on the cutting, considered in this study.

Rooting, however, was influenced by treatments. IBA in any dilution vehicle and NAA in $\mathrm{NaOH}$ were better superior than the other treatments. The benefits of using IBA are evidenced in Oliveira et al. (2012) who concluded that tea tree mini-cuttings collected from the apical portion of the branch, provide a higher percentage of rooting and better quality of the root system, when subjected to treatment with a hydroethanolic solution of IBA at $500 \mathrm{mg}$ $\mathrm{L}^{-1}$, analogous to the one used in the present study.

Comparatively, the treatment with NAA in $\mathrm{NaOH}$ showed a better result than NAA in hydroethanolic solution, showing that ethanol together with NAA, when in solution, have a behavior that does not favor a good dilution of the plant regulator, harming its performance.

Treatment with the hydroethanolic solution alone was not able to stimulate rooting. However, treatment with $\mathrm{NaOH}$ without plant regulator was able to stimulate number and length of roots in relation to control and ethanol. Although there are no reports in the literature on this behavior, the hypothesis arises that $\mathrm{NaOH}$ would be causing a type of localized stress, which may be linked to an elicitation route that activates the enzyme PAL (phenylalanine ammonia lyase) and compounds phenolics that give rise to auxin precursors. According to Chakraborty et al. (2001), the PAL activity increases in response to different types of stress, being considered as "stress protein", relating to the development of mechanisms for the protection and adaptation of plants to adverse situations (Castro et al., 2005b).

Finally, it was observed that the treatment IBA + $\mathrm{NaOH}$ promoted higher values of rooting, number and length of roots, being the most suitable treatment for the species (Table 2).

\section{Conclusions}

The plant growth regulator IBA (2000 $\left.\mathrm{mg} \mathrm{L}^{-1}\right)$ diluted in sodium hydroxide or hydroethanolic solution is the most suitable for the species $V$. curassavica. The application of NAA or IBA at a concentration of $500 \mathrm{mg} \mathrm{L}^{-1}$ using sodium hydroxide as a dilution vehicle promotes the best rooting results in the species $M$. alternifolia.

When applied without the auxins, dilution vehicles show no deleterious effects but also do not stimulate adventitious rooting in stem cuttings of $V$. curassavica and M. alternifolia.

\section{Author Contribution}

MP: Implementation and final evaluation of the greenhouse study and first draft of manuscript. ENG: Conception of the study and experimental design, implementation and final evaluation of the experiment and critical review of manuscript. UBR and LFSG: Analysis and interpretation of data, statistical analysis, bibliographic review, formatting and critical review of the manuscript. CD: Conception of the study, coordination of data collection and manuscript draft and critical review of manuscript. 


\section{Acknowledgments}

The authors acknowledge the financial support from Brazilian Federal Agency for Support and Evaluation of Graduate Education - CAPES (Finance Code 001).

\section{References}

ALENCAR, L.D.; CARDOSO, J.C. Paisagismo funcional: O uso de projetos que integram mais que ornamentação. Ciência, Tecnologia \& Ambiente, v.1, n.1, p.1-7, 2015.

BELNIAKI, A.C.; RABEL, L.A.D.N.; GOMES, E.N.; ZUFFELLATO-RIBAS, K.C. Does the presence of leaves on coleus stem cuttings influence their rooting? Ornamental Horticulture, v.24, n.3, p.206-210, 2019. https://doi.org/10.14295/oh.v24i3.1204

BHATTACHARYA, S.; BHATTACHARYA, N.C.; BHATNAGAR, V.B. Effect of ethanol, methanol and acetone on rooting etiolated cuttings of Vigna radiata in presence of sucrose and auxin. Annals of Botany, v.55, n.2, p.143-145, 1985.

BISCHOFF, A.; VENDRAMIM, D.; NUNES GOMES, E.; ZUFFELLATO-RIBAS, K., ENGEL, M.; MAGGIONI, R. Enraizamento de estacas de ervabaleeira em função de diferentes concentrações de ácido indol butírico e número de folhas. Revista de Ciências Agroveterinárias, v.16, n.1, p.41-47, 2017. https://doi. org $/ 10.5965 / 223811711612017041$

BRANDÃO, D.S.; MENDES, A.D.R.; SANTOS, R.R.; ROCHA, S.M.G.; LEITE, G.L.D.; MARTINS, E.R. Biologia floral e sistema reprodutivo da erva-baleeira (Varronia curassavica Jacq.). Revista Brasileira de Plantas Medicinais, v.17, n.4, p.562-569, 2015. https:// doi.org/10.1590/1983-084X/14_011

CASTRO, A.H.F.; ALVARENGA, A.A.; SOARES, A.M.; YOUNG, M.C.M.; PURCINO, A.A.C. Avaliação sazonal da atividade da fenilalanina amônia-liase e dos teores de fenóis e taninos totais em Byrsonima verbascifolia Rich. ex A. Juss.: uma espécie medicinal do cerrado. Revista Brasileira de Plantas Medicinais, v.7, n.3, p.45-55, 2005b.

CASTRO, C.; SILVA, M.L.; PINHEIRO, A.L.; JACOVINE, L.A.G. Análise econômica do cultivo e extração do óleo essencial de Melaleuca alternifolia Cheel. Revista Árvore, v.29, n.2, p.241-249, 2005a. https://doi. org/10.1590/S0100-67622005000200007

CHAKRABORTY, U.; DUTTA, S.; CHAKRABORTY, $B$. Drougth induced biochemical changes in young tea leaves. Indian Journal of Plant Physiology, v.6, n.1, p.103-106, 2001.
FACHINELLO, J.C.; HOFFMANN, A.; NACHTIGAL, J.C.; KERSTEN, E.; FORTES, G.R.L. Propagação de plantas frutíferas de clima temperado. Editora e Gráfica Universitária, 179p. 1994.

GILBERT, B.; FAVORETO, R. Cordia verbenacea DC Boraginaceae (Monografia). Revista Fitos. v.7, n.1, p.1725, 2012.

GOMES, E.N.; KRINSKI, D. Efeito do ácido indolbutírico no enraizamento de estacas foliares e caulinares de pariparoba (Piper umbellatum L.). Revista em Agronegócio e Meio Ambiente, v.13, n.2, p.661-678, 2020. https://doi. org/10.17765/2176-9168.2020v13n2p661-678

GOMES, E.N.; KRINSKI, D. Enraizamento de estacas caulinares de Piper crassinervium Kunth sob diferentes concentrações de ácido indolbutírico. Journal of Neotropical Agriculture, v.6, n.1, p.92-97, 2019. https:// doi.org/10.32404/rean.v6i1.192

GOMES, E.N.; KRINSKI, D. Piper crassinervium Kunth vegetative propagation: influence of substrates and stem cuttings positions. Revista Brasileira de Tecnologia Aplicada nas Ciências Agrárias, v.11, n.3, p.51-59, 2018. https://doi.org/10.5935/PAeT.V11.N3.05

GOMES, E.N.; KRINSKI, D. Propagação vegetativa de Piper umbellatum L. (Piperaceae) em função de substratos e comprimentos de estacas. Revista Scientia Agraria, v.17, n.3, p.31-37, 2016b. http://dx.doi.org/10.5380/rsa. v17i3.49695

GOMES, E.N.; KRISNKI, D. Propagação vegetativa de Piper amalago (Piperaceae) em função de tipos de estaca e substratos. Revista Cultura Agronômica, v.25, n.2, p.199-210, 2016a. https://doi.org/10.32929/24468355.2016v25n2p199-210

GOMES, E.N.; VIEIRA, L.M.; TOMASI, J.D.C.; TOMAZZOLI, M.M.; GRUNENNVALDT, R.L.; FAGUNDES, C.D.M.; MACHADO, R.C.B. Brown seaweed extract enhances rooting and roots growth on Passiflora actinia Hook stem cuttings. Ornamental Horticulture, v.24, n.3, p.269-276, 2018a. http://dx.doi. org/10.14295/oh.v24i3.1221

GOMES, E.N.; VIEIRA, L.M.; TOMAZZOLI, M.M.; DE MORAES FAGUNDES, C.; MACHADO, R.C.B.; ZUFFELLATO-RIBAS, K.C.; DESCHAMPS, C. Types of stem cuttings and treatment with indolebutyric acid for propagation of Lippia alba (linalool chemotype). Revista Cubana de Plantas Medicinales, v.23, n.3, 2018 b.

HARTMANN, H.T.; KESTER, D.E.; JUNIOR DAVIES, F.T.; GENEVE, R.L. Plant propagation: principles and practices. 8ed. New Jersey: Englewood Clipps, 900 p. 2011. 
HOELTGEBAUM, M.P.; REIS, M.S. Genetic diversity and population structure of Varronia curassavica: A medicinal polyploid species in a threatened ecosystem. Journal of Heredity, v.108, n.4, p.415-423, 2017. https:// doi.org/10.1093/jhered/esx010

LATOH, L.P.; GOMES, E.N.; ZUFFELLATO-RIBAS, K.C. Can indolebutyric and fulvic acids induce adventitious rhizogenesis on mini-cuttings from Brazilian native tibouchinas? Ornamental Horticulture, v.25, n.1, p.4248, 2019. http://dx.doi.org/10.14295/oh.v25i1.1257

LORENZI, H.; MATOS, F.J.A. Plantas medicinais no Brasil: nativas e exóticas. 2.ed. Nova Odessa: Plantarum, 2008. 544p.

LUZ, P.B. Propagation of Ornamental Plants. Ornamental Horticulture, v.25, n.3, p.217, 2019. https://doi. org/10.1590/2447-536x.v25i3.2086

MACHADO, M.P.; GOMES, E.N.; FRANCISCO, F.; BERNERT, A.F.; FILHO, J.C.B.; DESCHAMPS, C. Micropropagation and Establishment of Humulus lupulus L. Plantlets Under Field Conditions at Southern Brazil. Journal of Agricultural Science, v.10, n.7, 2018. https:// doi.org/10.5539/jas.v10n7p275

MARQUES, A.P.S.; BONFIM, F.P.G.; DANTAS, W.F.C.; PUPPI, R.J.; MARQUES, M.O.M. Chemical composition of essential oil from Varronia curassavica Jacq. accessions in different seasons of the year. Industrial Crops and Products, v.140, art.111656, 2019. http://dx.doi. org/10.1016/j.indcrop.2019.111656

MENDES, A.D.R. LACERDA, T.H.S.; ROCHA, S.M.G.; MARTINS, E.R. Reguladores vegetais e substratos no enraizamento de estacas de erva-baleeira (Varronia curassavica Jacq.). Revista Brasileira de Plantas Medicinais, v.16, n.2, p.262-270, 2014. https://doi. org/10.1590/S1516-05722014000200015

MIDDLETON, W.; JARVIS, B.C.; BOOTH, A. The effect of ethanol on rooting and carbohydrate metabolism in stem cuttings of Phaseolus aureus Roxb. New Phytologist, v.81, n.2, p.279-285, 1978.

OLIVEIRA, A.F.; CHALFUN, N.N.J.; ALVARENGA, Â.A.; NETO, J.V.; PIO, R.; OLIVEIRA, D.L. Estaquia de oliveira em diferentes épocas, substratos e doses de AIB diluído em $\mathrm{NaOH}$ e álcool. Ciência e Agrotecnologia, v.33, n.1, p.79-85, 2009. https://doi.org/10.1590/S141370542009000100011

OLIVEIRA, T.R.; TEIXEIRA, A.L.; BARBOSA, J.P.; de FEIRIA, S.N.B.; BONI, G.C.; MAIA, F.; ANIBAL, P.C.; WIJESINGHE, G.K.; HÖFLING, J.F. Melaleuca spp. essential oil and its medical applicability. A Brief Review. Brazilian Journal of Natural Sciences, v.3, n.1, p.249-249. 2020. https://doi.org/10.31415/bjns.v3i1.89
OLIVEIRA, Y.; ALCANTARA, G.B.; GUEDES, I.; PINTO, F.; QUOIRIN, M.; BIASI, L.A. Substratos, concentrações de ácido indolbutírico e tipos de miniestacas no enraizamento de melaleuca (Melaleuca alternifolia Cheel). Revista Brasileira de Plantas Medicinais v.14, p.611-616, 2012. https://doi.org/10.1590/S151605722012000400006

OLIVEIRA, Y.; SILVA, A.L.L.; PINTO, F.; QUOIRIN, M.; BIASI, L.A. Comprimento das estacas no enraizamento de melaleuca. Scientia Agraria, v.9, n.3, p.415-418, 2008. http://dx.doi.org/10.5380/rsa.v9i3.12508

PIGATTO, G.B.;GOMES,E.N.;TOMASIJ.C.; FERRIANI, A.P.; DESCHAMPS, C. Effects of indolebutyric acid, stem cutting positions and substrates on the vegetative propagation of Stevia rebaudiana Bertoni. Revista Colombiana de Ciencias Hortícolas, v.12, n.1, p.202-211, 2018. http://dx.doi.org/10.17584/rcch.2018v12i1.6631

PLANTS OF THE WORLD. 2020. Melaleuca alternifolia (Maiden \& Betche) Cheel. Available at: <http:// www.plantsoftheworldonline.org/taxon/urn:lsid:ipni. org:names:597833-1>. Accessed on: September 2 $2^{\text {nd }}, 2020$.

QUEIROZ, E.F.; FARO, R.R.A.; MELO, C.A.A. A biodiversidade brasileira como fonte de novas drogas: passado, presente e futuro. RDF - Revista de Fitoterapia, v.9, n.1, p.31-35, 2009.

SILVA, F.A.S.; AZEVEDO, C.A.V. Comparison of means of agricultural experimentation data through different tests using the software Assistat. African Journal of Agricultural Research, v.11, n.37, p.3527-3531, 2016. http://dx.doi.org/10.5897/AJAR2016.11523

TOFANELLI, M.B.D.; CHALFUN, N.N.J.; HOFFMANN, A.; CHALFUN JUNIOR, A. Efeito do ácido indolbutírico no enraizamento de estacas de ramos semilenhosos de pessegueiro. Pesquisa Agropecuária Brasileira, v.37, n.7, p.939-944, 2002. http://dx.doi.org/10.1590/S0100204X2002000700007

VIEIRA， L.M.; KRUCHELSKI， S.; GOMES， E.N.; ZUFFELLATO-RIBAS, K.C. Indolebutyric acid on boxwood propagation by stem cuttings. Ornamental Horticulture, v.24, n.4, p.347-352. 2018. https://doi. org/10.14295/oh.v24i4.1185

WENDLING, I.; BRONDANI, G.E.; BIASSIO, A.; DUTRA, L.F. Vegetative propagation of adult Ilex paraguariensis trees through epicormic shoots. Acta Scientiarum Agronomy, v.35, n.1, p.117-125, 2013. https://doi.org/10.4025/actasciagron.v35i1.15958 